\title{
ABOUT THE EUROPEAN EEL ANGUILLA ANGUILLA (LINNAEUS, 1758) OF THE DNIESTER RIVER
}

\author{
Sergey Filipenko, Mihail Mustea
}

T.G. Shevchenko Pridnestrovian State University, Tiraspol, Republic of Moldova e-mail: zoologia_pgu@mail.ru, mustya91@mail.ru

Abstract: The presence of the European eel Anguilla anguilla in the Dniester River has been reliably established. In May 2021, an European eel $94.5 \mathrm{~cm}$ long and $1400 \mathrm{~g}$ in weight was caught in the Dniester River near Tiraspol.

\section{Introduction}

The European eel Anguilla anguilla is one of the rarest fish of the r. Dniester. In 2008, it was included in the IUCN Red Data Book as a species "on the brink of extinction", with the Critically Endangered (CR) status, the eel is included in the Red Data Books of Moldova [1] and Transnistria [3], absent in the Red Data Book of Ukraine [4].

In the volume "Fishes, amphibians, reptiles" from the series "Animal world of Moldova" [2] in the article by E.N. Tomnatik dedicated to eel, noted:

"The European eel sometimes reaches $150 \mathrm{~cm}$ in length and $6 \mathrm{~kg}$ in weight. Males are much smaller: their length is $51 \mathrm{~cm}$, and their weight is 200-250 g”.

Regarding its presence in the reservoirs of Moldova, the following information is presented here: "The first mentions of eels in reservoirs of Moldova belong to K.F. Kessler (1857), who pointed to the capture of an eel about $90 \mathrm{~cm}$ in size in the Dniester above Yampol, L.S. Berg (1916) noted that eels in the lower reaches of the river were not uncommon, but there were no cases of catching this fish in Moldova ".

"An specimen of eel from the Turunchuk sleeve, $115 \mathrm{~cm}$ long, weighed $3 \mathrm{~kg}$. More often in the Dniester and Dubossary reservoir there were eels weighing 1337-1920, the length of which ranged from $87.5-99.7 \mathrm{~cm}$ ".

In the book "Commercial fish of the North-Western Black Sea region" [5], the following information is given: "In the Dniester delta, single small-sized specimens (2-3) of eels were still found in the spring of 1977 in a venture on burnt reaches. often at the mouths of the Dniester and Turunchuk before the construction of a new powerful Novodnistrovskaya hydroelectric power station in 1983, and after that eels became very rare, but, nevertheless, 1 large eel 80 cm long, probably the last time, was caught by fishermen at the mouth of the Dniester in April 2001 of the year".

T.D. Sharapanovskaya, director of the national park Yagorlyk, mentioned that one specimen of the eel was caught in the Dniester by fishermen in July 2005 near the pumping station of the village Butor.

Thus, there is practically no information in the literature on the registration of this species in the Dniester in recent decades; therefore, reliable data on the presence of eels in the Dniester are of great importance. 


\section{Results and discussions}

On May 12, 2021, in the Dniester near the city of Tiraspol near the ferry, a local fisherman caught an eel on a bunch of worms with a bottom tackle. At the time of withdrawal from the water, the fish had already died and could not be released into the river. The fisherman handed over the eel to the Department of Zoology and General Biology of the Faculty of Natural Geography of Pridnestrovian State University, where the fish was photographed, measured and weighed (fig. 1).

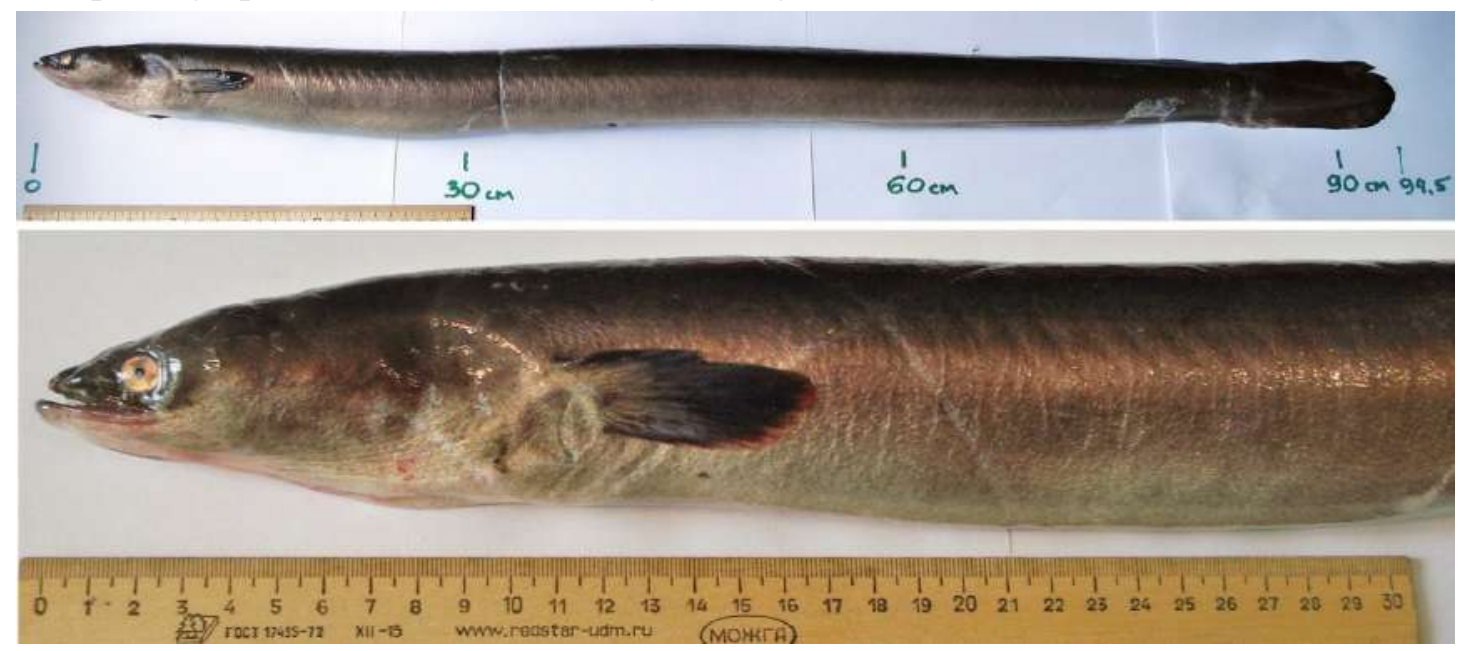

Figure 1. Eel caught in the Dniester (photo by the authors)

The eel had the following morphometric and weight characteristics: body length $94.5 \mathrm{~cm}$; body height $6.2 \mathrm{~cm}$; head length from end of snout to pectoral fin $11.4 \mathrm{~cm}$; weight $1400 \mathrm{~g}$.

\section{Conclusion}

It has been reliably established that the European eel Anguilla anguilla (Linnaeus, 1758 ) is very rare, but occurs in the lower reaches of the Dniester River.

\section{Bibliography}

1. Cartea Roşie a Republicii Moldova. Ed. a 3-a. Ch.: O.E.P. Ştiinţa, 2015 (Combinatul Poligr.), $492 \mathrm{p}$.

2. Животный мир Молдавии. Рыбы. Земноводные. Пресмыкающиеся. Отв. Ред. И.Ганя. Изд. Штиинца, Кишинев, 1981, с. 27-130.

3. Красная книга Приднестровской Молдавской Республики. 2-е изд. Тирасполь, 2020 (ГУИПП Бендерская типография „Полиграфист“»), 560 с.

4. Червона книга України. Тваринний світ. К.: Глобалконсалтинг, 2009, 600 с.

5. Щеголев И.В., Щеголев Е.И., Щеголев С. И. Промысловые рыбы Северо-Западного Причерноморья. Том 6. Аккерман, 2020, 350 стр. 